\title{
Innovative Urban Water Management as a Climate Change Adaptation Strategy: Results from the Implementation of the Project "Water Against Climate Change (WATACLIC)"
}

\section{Giulio Conte $^{1, *}$, Andrea Bolognesi ${ }^{2}$, Cristiana Bragalli ${ }^{2}$, Sara Branchini ${ }^{3}$, Alessandro De Carli ${ }^{4}$, Chiara Lenzi $^{2}$, Fabio Masi ${ }^{5}$, Antonio Massarutto ${ }^{4}$, Marco Pollastri ${ }^{3}$ and Ilaria Principi ${ }^{1}$}

1 Ambiente Italia S.r.1., Via Carlo Poerio 39, Milano 20129, Italy;

E-Mail: ilaria.principi@ambienteitalia.it

2 Department of Civil, Chemical, Environmental and Materials Engineering (DICAM), University of Bologna (Alma Mater), Viale Risorgimento 2; Bologna 40136, Italy;

E-Mails: and.bolognesi@unibo.it (A.B.); cristiana.bragalli@unibo.it (C.B.); chiara.lenzi5@unibo.it (C.L.)

3 Centro Antartide, Via Rizzoli 3, Bologna 40125, Italy;

E-Mails: sara.branchini@centroantartide.it (S.B.); marco.pollastri@centroantartide.it (M.P.)

4 Department of Economic Sciences, University of Udine, Via Palladio 8, Udine 33100, Italy; E-Mails: alessandro.decarli@unibocconi.it (A.D.C.); antonio.massarutto@uniud.it (A.M.)

5 IRIDRA S.r.1., Via La Marmora, 51, Firenze 50121, Italy; E-Mail: fmasi@iridra.com

* Author to whom correspondence should be addressed; E-Mail: giulio.conte@ambienteitalia.it; Tel.: +39-02-27744-1; Fax: +39-02-27744-222.

Received: 7 October 2012; in revised form: 29 November 2012 / Accepted: 11 December 2012 / Published: 19 December 2012

Abstract: The excessive use of water is damaging European groundwater and rivers: their environmental conditions are often below the "good status" that-according to Water Framework Directive 2000/60 — should be reached by 2015 . The already critical situation is tending to get worse because of climate change. Even in water rich countries, urban wastewater is still one of the main sources of water pollution. Currently, urban soil sealing and "conventional" rainwater management, which were planned to quickly move rainwater away from roofs and streets, are increasing the flood risk. "Green" technologies and approaches would permit a reduction in water abstraction and wastewater production while improving urban hydrological response to heavy rains. The Life+ WATACLIC project has been implemented to promote such sustainable technologies and approaches in Italy, 
however the results show huge difficulties: apparently water saving and sustainable urban water management have only low interest amongst the general public and even with public administrations and the relevant industrial sectors. In such a cultural and technical context, the project is bringing a new point of view to public debate. In the long term, the project will certainly have a positive impact, but most likely it will require more time than initially expected.

Keywords: water policy; sustainable water management; information campaign

\section{Introduction}

The excessive use of water is damaging European groundwater and rivers: their environmental conditions are often below the "good status" that-according to the Water Framework Directive 2000/60 - should be reached by 2015 [1]. In Italy the situation is still critical: more than 50\% of the river water quality sampling stations in 2010 did not reach the "good status" (Table 1).

Table 1. River water quality in Italy, year 2010. Water quality classification according to EU Directive 2000/60 criteria; Data from ISPRA [2].

\begin{tabular}{ccccccc}
\hline Geographical area & Very good \% & Good \% & Sufficient \% & Poor \% & Very poor \% & Sampling stations \\
\hline Northern Italy & 11 & 58 & 24 & 7 & 0 & 131 \\
Central Italy & 4 & 38 & 35 & 16 & 7 & 246 \\
Southern Italy & 3 & 32 & 43 & 19 & 3 & 172 \\
\hline Italy & 6 & 40 & 35 & 15 & 4 & 549 \\
\hline
\end{tabular}

The already critical situation is tending to get worse because of climate change. According to IPCC [3] and EU [4], one of the most important effects of Climate Change concerns water: beside the risk of more uneven precipitation patterns throughout the continent, an increase of dry periods is predicted especially in the southern part of Europe. In the coming years, therefore, several European areas, already experiencing water stress - such as Greece, Southern Italy and Spain-will evolve towards more severe conditions (Figure 1).

High water abstraction is a major problem in Mediterranean countries, where a reduction of water use - especially in the water intensive sector of agriculture - is absolutely needed in order to increase natural water flow in rivers and groundwater [5]. In Southern Europe, then, a sustainable water management approach should combine efficient water use in all sectors, together with a reduction of pollution loads due to urban wastewater along with industrial and agriculture sources. However, even in water rich countries, such as those in Northern Europe, urban wastewater is still one of the main sources of water pollution: wastewater treatment performance would benefit highly from a reduction in domestic water use (biological treatment processes are concentration limited: the lower the concentration of the treatment inflow, the larger the pollution load at the effluent after treatment). Currently, urban soil sealing and "conventional" rainwater management, planned to quickly move rainwater away from roofs and streets, are increasing the flood risk. 
Figure 1. Water Exploitation Index in EU countries. WEI is the ratio of annual freshwater abstraction to long-term water availability. Data from EFA core set indicator 018 [6].

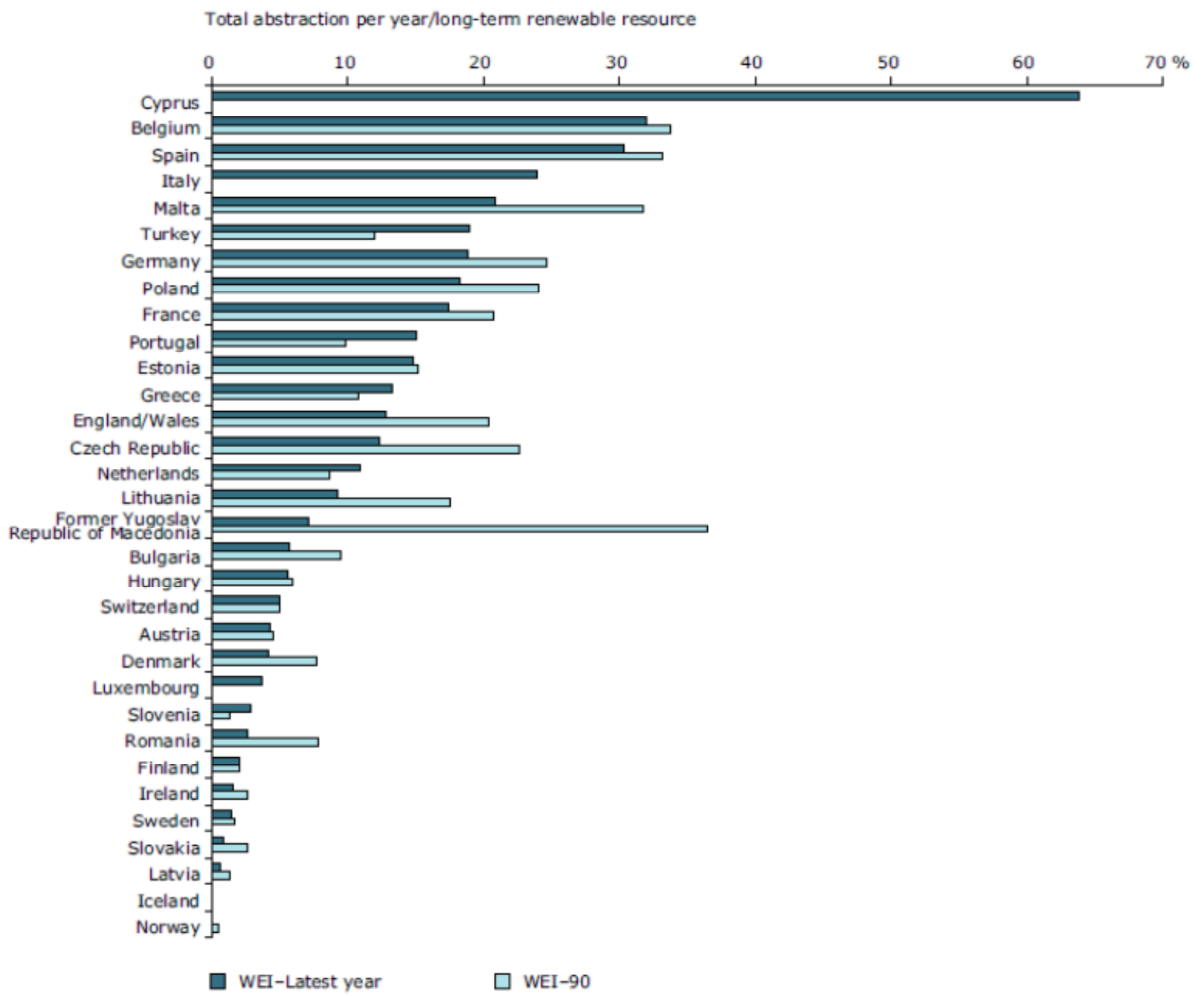

In Italy, besides the irrigation sector (responsible for more than 25 billion of water withdrawal, 50\% of the country's water use), the excessive use of water concerns urban water use. From 1987 to 2008 water withdrawal for urban use increased by more than 1 billion $\mathrm{m}^{3}$ (cubic meters), exceeding nine billion $\mathrm{m}^{3}$ of yearly withdrawal (Figure 2), while the per capita daily consumption of water delivered to households, even though slightly decreasing, is amongst the highest in Europe (more than $0.25 \mathrm{~m}^{3} /$ inhabitant/day) [7].

Thus urban water use in Italy is affected by two major problems. First, the excess of water withdrawal: due to the poor performance of the distribution network nearly $40 \%$ of water withdrawn is lost on the way and does not reach the final users. The problem has become worse in recent times: that is why in 2008 the total water volume withdrawn increased, while the volume delivered decreased. Secondly, the high per capita water consumption and, consequently, the dilution of the wastewater collected $\left(\mathrm{BOD}_{5}\right.$ concentration is very often below $\left.150 \mathrm{mg} / \mathrm{L}\right)$, affect the pollution removal capacity of the treatment plants, which usually work better when more concentrated liquids are to be treated. Moreover, the "centralised" wastewater treatment approach adopted in past decades results in the discharge of huge mass fluxes at a single point. Thus, even the outflows which respect legal concentration limits, discharge at a very large flow rate and, consequently, contain a large amount of 
pollutants. Whenever the receiving water flow is unable to dilute the treatment plant effluents, such as during summer low flows, most river stretches located downstream do not meet the WFD 2000/60 quality standards for "good status".

Figure 2. Water withdrawal and consumption for urban use in Italy. Data are from ISTAT [7].

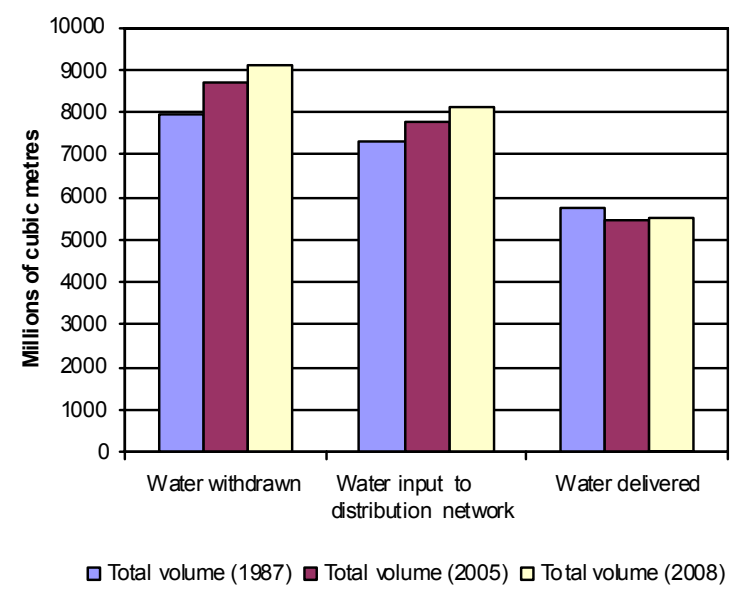

(a)

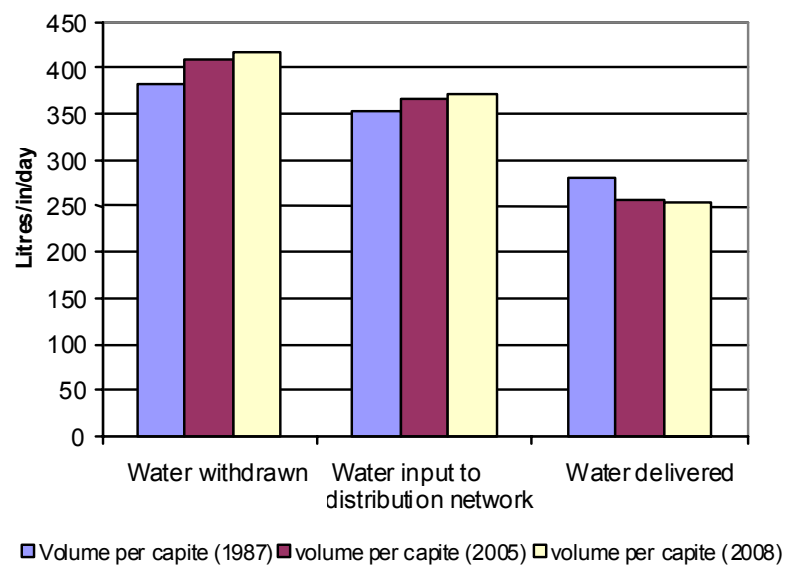

(b)

What is even more surprising is that the high per capita consumption is not perceived as a problem, either by the public, or by water service operators, who in their provisional plans expect to increase the water volume for distribution for urban use by 2020 (Table 2).

Table 2. Expected water volume distributed in Italy for urban use (millions of $\mathrm{m}^{3}$ ) [8].

\begin{tabular}{cccccc}
\hline Geographical area & $\mathbf{2 0 1 0}$ & $\mathbf{2 0 1 1}$ & $\mathbf{2 0 1 2}$ & $\mathbf{2 0 1 5}$ & $\mathbf{2 0 2 0}$ \\
\hline North-West & 1681 & 1683 & 1685 & 1693 & 1706 \\
Nord-East & 1165 & 1168 & 1171 & 1182 & 1194 \\
Centre & 1010 & 1012 & 1014 & 1019 & 1027 \\
South & 1141 & 1149 & 1156 & 1174 & 1190 \\
Islands & 573 & 584 & 596 & 606 & 614 \\
\hline Italy & 5570 & 5596 & 5622 & 5674 & 5731 \\
\hline
\end{tabular}

Water Authorities do not comprehend the need of more rational water use: a recent report [8] carried out for the Italian Government by the association of water management companies, states: "Data from Water Plans clearly show - contrary to what is asked by the European Water Framework Directive - an increasing trend in water demand, clearly showing the Italian difficulties to conform to the EU policy orientation". Similarly, the need to reduce water consumption at household level is not widely perceived by the various stakeholders.

There are several causes of the present situation of water management in Italy: the most important being the lack of knowledge about new approaches of sustainable water management. Technical and administrative operators of the water sector, having been trained to operate the water service with the sole aim of satisfying final users, have very little knowledge of the availability of new technical, financial and communication tools able to bring households towards a more sustainable water use. Another important aspect concerns the water cost, that in Italy, according to Global Water Intelligence [9] 
is among the lowest in Europe, ranging between 0.50 and $2.50 € / \mathrm{m}^{3}$. However the situation does vary throughout the country and recent data shows that water consumption is higher where cost is lower (Figure 3).

Figure 3. Trend of water consumption related to water tariffs in main Italian cities. Elaboration of the authors on data from ISTAT [7].

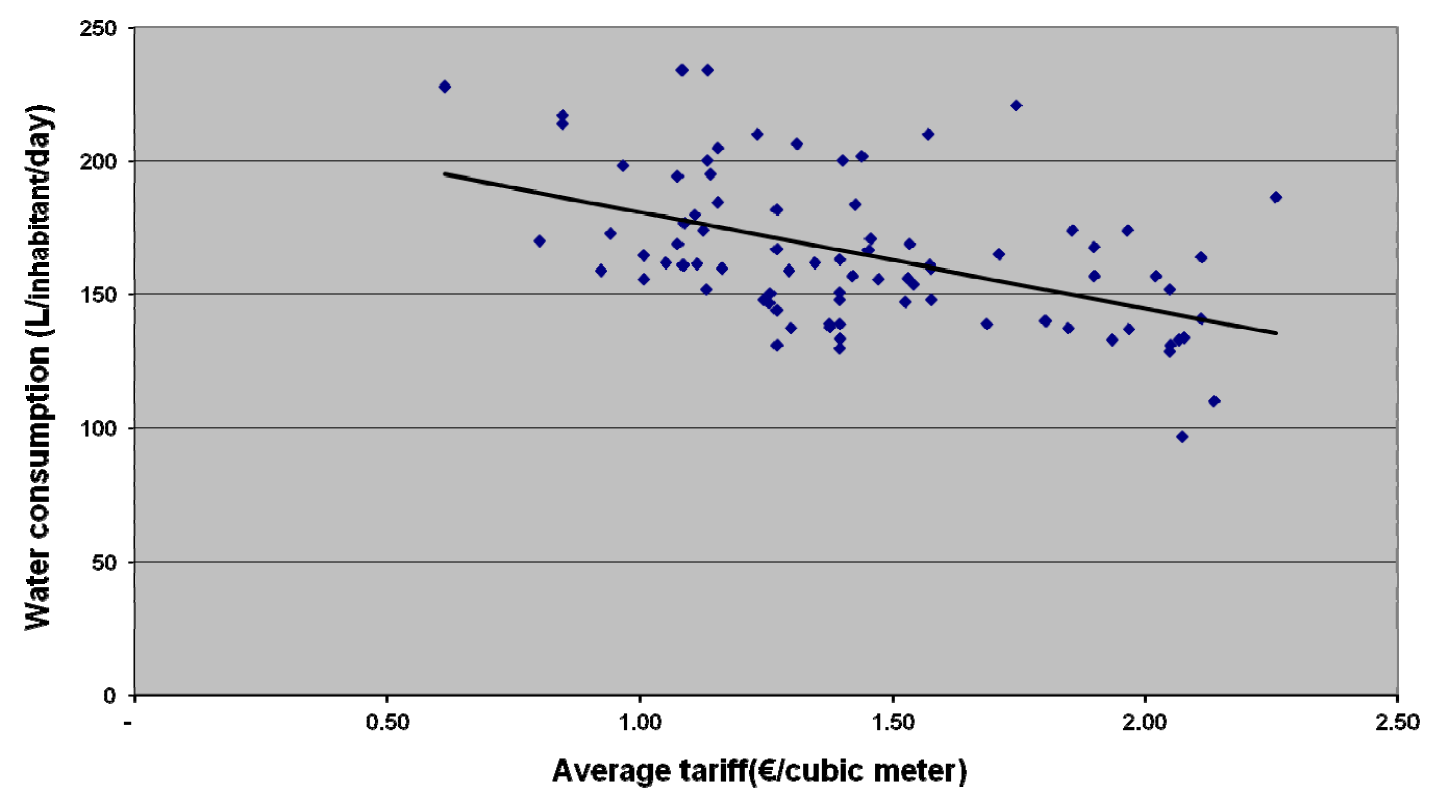

\section{Methodology: WATACLIC-An Information and Communication Project to Disseminate}

\section{Best Practice}

As recently recognized by the European Environmental Agency "to prevent urban water crises, we need to manage water resources effectively at every stage: from the supply of clean water to its different uses by the consumers. This could involve reducing consumption as well as finding new ways of collecting and using water. Water management should also be better integrated within wider urban management while taking into account characteristics of the local environment" [10].

In this context Sustainable Water Management (SWM) technologies and approaches would allow a reduction of water abstraction and wastewater production while improving urban hydrological response to heavy rains [11]. Different kinds of SWM solutions can be adopted by final users or by water service operators. They range from very simple technologies - such as flow reduction tools for taps and showers or low flushing toilets - to the use of alternative water sources (rain water or treated greywater) for nondrinkable uses [12,13], to urine separation and dry sanitation equipment [14,15], to pressure management and water loss control in the distribution network [16,17], to the large "family" of SUDS (Sustainable Urban Drainage Systems) [18].

When the WATACLIC project was conceived, back in 2008, the question was: How can such technologies and approaches be promoted throughout Europe, and specifically in Italy? Information and communication tools play a strategic role for innovation in the field of urban and domestic water management. Moreover sustainable water management practices and approaches concern not only technicians who operate the water services, but also other stakeholders: public administrators, NGOs, households, and plumbers. The objective of WATACLIC is to provide proper information to different 
key stakeholders to promote innovative approaches to urban water management in order to disseminate culture and technologies through specific campaigns focussed on different target audiences: bodies in charge of water planning and management, urban planners, local authorities, the toilet and sanitation manufacture industry, and the building sector. After the creation of a database of SWM technologies (more than 60 records) and good practice experiences (18 records), five different information campaigns were conceived (refer to Table 3 for more information on these activities). Each campaign envisaged that workshops be organized by WATACLIC partners (Ambiente Italia, IRIDRA, the Universities of Bologna and Udine, Centro Antartide, the NGO that manages the national website on water saving) together with local partners (regional governments, local authorities, universities and research centres, and NGOs). The five campaigns had different target audiences:

- Water and Rules - Local authorities and urban planners: what solutions can be applied and how to promote them through urban planning and building regulations.

- Water and Money-Water authorities: water tariffs and other economic tools to discourage excessive use of drinking water and to promote innovative solutions; how to ensure social equality and not to penalize large households, assuring, in the meantime, financial feasibility of water services and investments.

- Water and Energy - Water and wastewater management utilities: innovative solutions to reduce water losses and improve the energy efficiency of water services.

- Water and Citizens-Public administrations, utilities and NGOs: conception of effective information campaigns in order to encourage consumers to adopt a more responsible behavior towards water consumption and to use technologies that improve water and energy efficiency (low consumption sanitation devices and home appliances).

- Water and Innovation-Industry and plumbing service enterprises: disseminate knowledge and technologies for sustainable water management with regard to domestic plumbers.

Table 3. Summary of information activity of the WATACLIC project.

\begin{tabular}{|c|c|c|c|}
\hline Campaign & Target audience & Information contents & Responsible \\
\hline $\begin{array}{l}\text { Water and } \\
\text { rules }\end{array}$ & $\begin{array}{l}\text { Local Authorities and } \\
\text { urban planners }\end{array}$ & $\begin{array}{l}\text { Best practices of urban planning to promote: } \\
\text { Rainwater harvesting; } \\
\text { Greywater separation and re-use; } \\
\text { Decentralised wastewater treatment systems } \\
\text { (constructed wetlands); } \\
\text { Sustainable urban drainage systems (SUDS) }\end{array}$ & $\begin{array}{l}\text { Ambiente Italia } \\
\text { \& IRIDRA }\end{array}$ \\
\hline $\begin{array}{l}\text { Water and } \\
\text { money }\end{array}$ & Water Authorities & $\begin{array}{c}\text { Tariffing systems, economic incentives in } \\
\text { water policy }\end{array}$ & $\begin{array}{l}\text { University of } \\
\text { Udine }\end{array}$ \\
\hline $\begin{array}{l}\text { Water and } \\
\text { energy }\end{array}$ & $\begin{array}{l}\text { Water and wastewater } \\
\text { management utilities }\end{array}$ & $\begin{array}{l}\text { Leakage detection, pressure control, pumping } \\
\text { optimization, micro energy production plants }\end{array}$ & $\begin{array}{l}\text { University of } \\
\text { Bologna }\end{array}$ \\
\hline $\begin{array}{l}\text { Water and } \\
\text { citizens }\end{array}$ & $\begin{array}{l}\text { Public Administrations, } \\
\text { Utilities and NGOs }\end{array}$ & $\begin{array}{l}\text { Effective information campaigns: target, } \\
\text { timing, old and new media, monitoring }\end{array}$ & $\begin{array}{l}\text { Università Verde } \\
\text { di Bologna }\end{array}$ \\
\hline $\begin{array}{l}\text { Water and } \\
\text { innovation }\end{array}$ & $\begin{array}{l}\text { Industry and plumbing } \\
\text { service enterprises }\end{array}$ & $\begin{array}{l}\text { Water saving (tap aerators, low flush toilets, } \\
\text { etc.), rainwater harvesting and re-use, } \\
\text { segregation and re-use of greywater, }\end{array}$ & $\begin{array}{l}\text { Ambiente Italia } \\
\text { \& IRIDRA }\end{array}$ \\
\hline
\end{tabular}




\section{Project Results}

Apparently, in Italy water is not a very "trendy" issue. Involvement of the target audiences in WATACLIC campaigns has proved to be quite difficult: more events than originally planned have been organized in order to reach a satisfactory number of participants. In addition interviews with the participants showed a general, low-medium level of knowledge of the themes discussed during the workshops as well as difficulties in adopting the proposed measures and approaches in their professional activities (Table 4, gives an example of interviews for two of the campaigns).

Table 4. The results of most of the information from questionnaires that participants were asked to fill in before the events of the campaigns; Water and Rules and Water and Money. Answers are given on a 1 (lowest)-5 (highest) scale.

\begin{tabular}{cccc}
\hline Themes & $\begin{array}{c}\text { State of knowledge on } \\
\text { the proposed themes }\end{array}$ & $\begin{array}{c}\text { Interest in the } \\
\text { proposed themes }\end{array}$ & $\begin{array}{c}\text { Interest in adopting the } \\
\text { proposed strategies }\end{array}$ \\
\hline $\begin{array}{c}\text { Techniques to reduce rainwater in sewage } \\
\text { Decentralized treatment systems }\end{array}$ & 2.4 & 3.7 & 3.8 \\
$\quad \begin{array}{c}\text { (isolated neighborhoods, spillways) } \\
\text { Water saving and re-use }\end{array}$ & 2.2 & 3.6 & 3.6 \\
$\begin{array}{c}\text { Integration of water management principles } \\
\text { in building regulations }\end{array}$ & 3.0 & 4.3 & 4.2 \\
$\begin{array}{c}\text { Different tariff structures and their effect to } \\
\text { reach environmental, economic, financial } \\
\text { and social goals }\end{array}$ & 2.3 & 4.0 & 3.9 \\
$\quad 3.4$ & 4.5 & 3.3 \\
$\begin{array}{c}\text { Financial instruments for urban water } \\
\text { services in Italy and in other countries }\end{array}$ & 3.5 & 4.4 & 3.4 \\
Tools for territorial and social equality & 2.9 & 4.0 & 3.2 \\
\hline
\end{tabular}

Campaigns that showed higher participation rates (Table 5) were: water and money, confirming the existing awareness on the economic issues, and water and energy, the most "technical" one, targeted to a very specialized audience. Water and citizens and water and innovation had the worst participation performance. The low participation in events focusing on information campaigns water and citizens is maybe due to the sharp reduction of funds for communication activities linked to the recent financial crisis. However, more significant is the lack of interest on the issue by professional plumbers (water and innovation) who apparently do not identify domestic water saving innovative technologies as a profitable sector for their day-to-day work. The high number of participants in the water and rules campaign is mainly due to the high number of students participating in the two special events organized with technical and scientific institutions (universities, professional associations and bodies). The latter demonstrating an increasing interest of students and academic institutions in the themes proposed. 
Table 5. The results of the campaigns in terms of participants. Note that students who attended the events are not included in "participating entities" but only in "participants".

\begin{tabular}{ccccccc}
\hline \multirow{2}{*}{ Campaign } & \multicolumn{3}{c}{ Participating entities } & \multicolumn{3}{c}{ Participants } \\
\cline { 2 - 6 } & Achieved & Expected & Result (\%) & Achieved & Expected & Result (\%) \\
\hline Water and Rules & 303 & 400 & $76 \%$ & 661 & 500 & $132 \%$ \\
Water and Money & 117 & 80 & $146 \%$ & 250 & - & - \\
Water and Citizens & 109 & 150 & $73 \%$ & 177 & - & - \\
Water and Energy & 155 & 75 & $207 \%$ & 286 & - & - \\
Water and Innovation & - & - & - & 50 & 60 & $83 \%$ \\
\hline Total & 684 & 705 & $97 \%$ & 1424 & 560 & $127 \%$ \\
\hline
\end{tabular}

The project concept claimed that a significant decrease of water abstraction for urban use in Italy could be obtained by introducing the "WATACLIC" concepts in the ordinary activities of the targeted entities. More specifically the project objectives were the following:

- To introduce new rules in urban planning to help the diffusion among final users of technologies/strategies such as rainwater harvesting, greywater recycling and other techniques able to allow more sustainable urban water use.

- To adopt tariff schemes aimed at discouraging unwise use of water.

- To increase global efficiency (in terms of water and energy consumptions) of water supply systems.

- To adopt more effective awareness raising campaigns directed at the general public.

- To improve knowledge and awareness of plumber professional organization concerning water saving techniques.

- To emphasize the link between water use and energy consumption.

Have such objectives been reached?

\subsection{New Urban Rules}

In Italy, according to the report produced by the ONRE (National Observatory on Municipal Building Regulations) of Legambiente and CRESME (Economical, Sociological and Market Research Center), referring to data from 2011, 530 of the 8092 Italian Municipalities already include in their building regulation, rules on sustainable water management. The very large part—more than $90 \%$ - of them have new regulations, approved after the year 2005. In the coming years the building regulations of all the remaining Municipalities will be progressively updated and-considering also the need to fulfill the requirements of the new Climate Change Adaptation Plans-hopefully they will include the sustainable water management new rules. WATACLIC is playing a significant role in driving such a process by its "water and rules" campaign: 45 Municipalities of the 59 that participated in the events are not listed in the ONRE Report, and several professional experts who participated in the campaign will work in the coming years with other Municipalities to renew their regulations. A few important Provinces also participated in the Water and Rules events: among them Vicenza, Mantova and Rome are willing to publish guidelines for their Municipalities to urge them to include sustainable water management rules. Moreover, the success of the WATACLIC website-where all project materials are downloadable — in the past months (the number of accesses grew from 2000 as of June 2011 to an 
average of 5000 after May 2012), and the interest showed by several media outlets on the project, has shown the project to contribute a significant role in the improvement of water urban planning and building regulations.

However it must be underlined that the process of renewing Municipality rules including water aspects will require more time than expected. Although the SWM technologies and approaches proposed are of growing interest in the scientific community and are reckoned to be effective both for household [19-22] and urban contexts [23,24], the economic crisis is progressively reducing the activities of Municipalities in the environmental sector and-according to the experience of WATACLIC project - water now has a very low ranking in the interest of public administrations.

\subsection{Water Tariffs and Other Economic Instruments}

Water tariffs and the cost of water services have been key topics of public debate in Italy during the past years (the national referendum held in June 2011 established that water management services could not be operated by private companies). On the other hand, the uncertainty of the general legal framework and the unclear position of Water Authorities (ATO) has very often brought the discussion, during the water and money events, to embrace more general issues, rather than concentrating on tariff schemes and other economic instruments able to discourage high domestic consumption, guarantee infrastructure development and maintenance [25-27], and stimulate new technologies (rain water harvesting, greywater re-use).

In May 2012 the Italian Energy Authority, after the Law n. 214/2011 [28] assigned to the same Authority competencies on Water Services Regulation, started a public consultation on a new national water tariff scheme. In the meantime, while general public opinion is still very much worried about the possible growth of water tariffs, the environmental movement requests full application of the "polluter pays" principle, clearly saying that the huge investments in the water sector needed to fulfill the requirements of the Directive 2000/60, have to be paid by water users.

Thus, the WATACLIC team is confident that in a reasonable time (hopefully before new general elections in April 2013) the objective of WATACLIC (to adopt tariff schemes aimed at discouraging unwise use of water) will be reached at a national scale, by a new national tariff scheme; WATACLIC will have certainly contributed to such a result, as well as enhancing and stimulating the debate on these issues among relevant stakeholders.

More difficult will be the adoption of economic tools to stimulate new technologies. A proposal circulated during WATACLIC campaigns to include some water technologies (rain water harvesting, greywater re-use) among the building restoration solutions that receive fiscal incentives to promote energy efficiency, raised interest by Environmental NGOs but has not yet achieved public debate.

\subsection{Efficiency of the Water Supply System}

It is probably the most sensitive topic for Italian public opinion, and there is a general agreement that something has to be done to reduce water losses in a large part of the distribution networks, particularly in the south of Italy. The WATACLIC campaign water and energy concerned very technical aspects and was targeted at a very technical audience: nevertheless participation was very high. The proposed technical solutions to improve water and energy efficiency of distribution networks 
are in the WATACLIC database, downloadable from the website, and they will be disseminated far beyond the project lifespan as their efficacy is well documented [29,30]. Several Water Utilities that have been involved in the organization of the WATACLIC campaign (Hera, ACEA, Iren, AMAP, Abbanoa) are planning interventions to reduce water losses and the WATACLIC partner responsible for the campaign (University of Bologna), is already providing scientific advice to some of them. Thus, it is reasonable to forecast a significantly positive impact of the WATACLIC project on the topic. It is more difficult to quantify the expected reduction of losses, as well as to predict a plausible timetable: the possibility to act, in fact, depends on the availability of financial resources, which is linked to the new tariff scheme and to other financial aspects that are still on the table.

To further increase the impact of the project on this topic, and also to press for political commitments from the water utilities, Federutility (the Italian association of all public companies managing water in the country) will be involved as partner in the organization of the WATACLIC final conference and, after the project end, as co-promoter of the national annual communication campaign (water "wise" use national day).

\subsection{Raising Awareness of Final Users and of Professional Plumbers}

The campaigns water and citizens and water and innovation - the first one targeted at several actors organizing awareness raising campaigns for the general public, the second one targeted to professional plumbers to inform them about sustainable water management technologies - are the campaigns that achieved the worst results, in terms of participation at the events.

The WATACLIC team, however, is confident that the objective "to adopt more effective awareness raising campaigns directed to the general public" will be attained, at least partially. The topic of "how to communicate water saving concepts to citizens" needs to be re-considered, once the new tariffing scheme has been adopted. Communication campaigns, in fact, could be much more effective. Additionally, a clear "price signal" on the value of water needs to be given.

The lack of interest by plumbers and by the sector industries is probably the most problematic issue. Project targets - apparently quite easy to meet and to be involved in-were not fully reached, even though the structure of the events was simplified and adapted to allow more replication of the events and a wider participation. The objective "to improve knowledge and awareness of plumber professional organization concerning water saving techniques" has therefore only partially been achieved.

It appears to be very clear that the "environmental awareness" of the industrial sector will not contribute very much to disseminate "sustainable" technologies, if the market (specifically households and the building industry) does not ask for them. The campaigns presented very interesting technologies and products already available on the Italian market (e.g., very efficient toilets using less than five liters for a complete flush), but apparently water efficiency is not an important criterion used to select bathroom and toilet equipment by final users.

Besides legally binding building regulations and price signals, a wider policy is needed to inform citizens about the water consumption "performance" of toilet equipment and household appliances; something similar to what already exists for energy consumption. 


\section{Conclusions}

In Italy, compared to other environmental issues, water saving and sustainable urban water management are only of low interest among the general public and specific audiences, such as public administrations and the relevant industrial sectors. The domestic and urban water issue is perceived as a problem only in the case of a poor distribution service and, even among experts, there is a very little awareness about the important logical links related to water, such as:

- Water abstraction $\rightarrow$ decrease water flow of rivers and groundwater $\rightarrow$ increase in pollution risk;

- Water use $\rightarrow$ increase with dilution of wastewater $\rightarrow$ higher costs and lower treatment efficiency;

- Urban design $\rightarrow$ rainwater management $\rightarrow$ water pollution and flood risk.

However it has been demonstrated that when the problems related to water as a scarcity or as a flood risk became relevant and the people in charge of their management perceived them as such, then the activities and campaigns that they put into practice can be very effective (see Table 6).

Table 6. A few examples of sustainable water management programs at international level.

\begin{tabular}{|c|c|c|c|c|}
\hline City & Problem targeted & Actions adopted & Results & Source \\
\hline $\begin{array}{l}\text { Zaragoza; } \\
\text { Spain }\end{array}$ & $\begin{array}{l}\text { Water scarcity, } \\
\text { particularly a } \\
\text { drought in the early } \\
\text { 1990s }\end{array}$ & $\begin{array}{l}\text { - Reduction of network losses; } \\
\text { - Introduction of regulations for urban } \\
\text { and buildings development aiming at } \\
\text { reducing final consumption; } \\
\text { - Communication campaigns }\end{array}$ & $\begin{array}{l}\text { Decline in per capita domestic } \\
\text { water consumption from } 136 \\
\text { liters } 2000 \text { to } 105 \text { in } 2009 \text {. }\end{array}$ & [31] \\
\hline $\begin{array}{l}\text { Fukuoka, } \\
\text { Japan }\end{array}$ & $\begin{array}{l}\text { Frequent and severe } \\
\text { droughts resulting in } \\
\text { major water } \\
\text { shortages for the city }\end{array}$ & $\begin{array}{l}\text { addressed at the general public } \\
\text { - Water Rates (surcharge on water use); } \\
\text { - Leak Prevention and Detection } \\
\text { (minimize leakage within individual } \\
\text { residences as well as the water } \\
\text { distribution system itself); } \\
\text { - Residential Indoor Use (Water- } \\
\text { saving devices have been installed; } \\
\text { - Landscaping/Outdoor Use (The city } \\
\text { also encourages the collection and } \\
\text { re-use of rainwater for outdoor } \\
\text { watering needs to reduce the usage of } \\
\text { potable water). }\end{array}$ & $\begin{array}{l}\text { Data have shown that water } \\
\text { savings from Fukuoka's water } \\
\text { distribution regulation system } \\
\text { amount to approximately } \\
5 \text { million liters per day and } \\
\text { that Fukuoka City consumes } \\
\text { about } 20 \% \text { less water than } \\
\text { other comparably sized cities }\end{array}$ & [32] \\
\hline $\begin{array}{l}\text { Bruxelles, } \\
\text { Belgium }\end{array}$ & Flood risks & $\begin{array}{l}\text { - To reduce the impact of soil sealing; } \\
\text { - To design the wastewater network } \\
\text { (with special reference to combined } \\
\text { sewer overflows and extended } \\
\text { retention basins); } \\
\text { - To favor rainwater retention. }\end{array}$ & $\begin{array}{l}\text { New building regulations such } \\
\text { as rainwater collection } \\
\text { measures and green roof for } \\
\text { new settlements have been } \\
\text { established }\end{array}$ & [33] \\
\hline
\end{tabular}

Water tariffing should be correctly used to assure the "full sustainability" (environmental, social and financial) of the water management system. A "demand side management" instrument, tariffing system should discourage water abstraction: including water losses in the distribution process and, 
through "price signaling", excessive consumption by final users. Fulfilling the "full cost recovery" principle, water tariffs should guarantee the financial sustainability of water service operators and of their investments. Last but not least, tariffs should take into consideration the low-income population, avoiding water costs becoming unaffordable. Carefully designed, economic instruments could also play a role to reduce the hydrological impact of soil sealing and urban pollution load (wastewater and diffuse pollution) to water bodies.

Another key action is to improve knowledge transfer by introducing new concepts and approaches on water management among high-level teaching institutions (high schools and universities), which are already showing a high interest.

In order to speed the process up, the elaboration of national prescriptive guidelines on "water correct" urban planning would be helpful, together with design and building regulations as well as a training course for public officers involved in urban planning.

In order to increase the awareness about the water issue, institutions, public bodies, and NGOs have to promote and organize a national long term educational, cultural and information program, targeted at all categories of stakeholders. Broad communication campaigns, coordinated at national level and implemented by regional and local partners, are needed.

When the previous actions have been accomplished, the rest will follow: water management companies will invest to improve their systems, local authorities will update their urban planning and building regulations and - together with NGOs - they will organize effective information campaigns, final users will look for more efficient technologies and the market (plumbing and building operators and sanitation industry) will answer positively.

\section{Acknowledgments}

WATACLIC is a project cofounded by European Commission under the Life + program. Code of the project is LIFE08 INF/IT/308.

\section{References}

1. EU (European Union). Establishing a framework for Community action in the field of water policy. In Water Framework Directive 2000/60. Official Journal of the European Union: Brussels, Belgium, 2000. Available online: http://eur-lex.europa.eu/LexUriServ/LexUriServ.do?uri= OJ:L:2000:327:0001:0072:en:PDF (accessed on 11 December 2012).

2. ISPRA (Istituto Superiore per la Protezione e la Ricerca Ambientale). Annuario Dati Ambientali 2011 (in Italian); ISPRA: Roma, Italy, 2012. Available online: http://annuario.isprambiente.it (accessed on 27 September 2012).

3. IPCC (Intergovernmental Panel on Climate Change). Fresh water resources and their management. In Contribution of Working Group II to the Fourth Assessment Report of the Intergovernmental Panel on Climate Chang; Parry, M.L., Canziani, O.F., Palutikof, J.P., van der Linden, P.J., Hanson C.E., Eds.; Cambridge University Press: Cambridge, UK, 2007; Chapter 3. Available online: http://www.ipcc.ch/publications_and_data/ar4/wg2/en/ch3.html (accessed on 27 September 2012). 
4. EU. Adapting to Climate Change: Towards a European Framework for Action; Technical Paper for Commission of the European Communities: Brussels, Belgium, 2009. Available online: http://ec.europa.eu/clima/policies/adaptation/documentation_en.htm (accessed on 27 September 2012).

5. EEA (European Environmental Agency). Towards Efficient Use of Water Resources in Europe; Report n.1/2012; EEA: Copenhagen, Denmark, 2012. Available online: http://www.eea.europa.eu/ publications/towards-efficient-use-of-water (accessed on 27 September 2012).

6. EEA. Use of Freshwater Resources (CSI 018); EEA: Copenhagen, Denmark, 2010. Available online: http://www.eea.europa.eu/data-and-maps/indicators/use-of-freshwater-resources/use-offreshwater-resources-assessment-2 (accessed on 27 September 2012).

7. UTILITATIS 2010-Studio ed Elaborazione di un Quadro Operativo per l'impianto Gestionale dei Servizi Pubblici Locali (in Italian); Report Commissioned by the Presidenza del Consiglio dei Ministri, Dipartimento Affari Regionali: Roma, Italy, 2010.

8. Zetland, D. Global Water Tariffs Continue Upward Trend. GWI (Global Water Intelligence), September 2011; Volume 12, Issue 9. Available online: http://www.globalwaterintel.com/ archive/12/9/market-profile/global-water-tariffs-continue-upward-trend.html (accessed on 27 September 2012).

9. ISTAT.IT. (Istituto Nazionale di Statistica Online Databases). Available online: http://www.istat.it/it/prodotti/banche-dati (accessed on 27 September 2012).

10. EEA. Water in the City. Available online: http://www.eea.europa.eu/articles/water-in-the-city (accessed on 27 September 2012).

11. Larsen, T.; Gujer, W. The concept of sustainable urban water management. Water Sci. Technol. 1997, 35, 3-10.

12. Li, Z.; Boyle, F.; Reynolds, A. Rainwater harvesting and greywater treatment systems for domestic application in Ireland. Desalination 2010, 260, 1-8.

13. Fangyue, L.; Wichmanna, K.; Otterpohl, R. Review of the technological approaches for grey water treatment and reuses. Sci. Total Environ. 2009, 407, 3439-3449.

14. Otterpohl, R.; Buzie, C. Wastewater: Reuse-oriented wastewater systems-Low- and high-tech approaches for urban areas. In Waste, a Handbook for Management, 1st ed.; Letcher, T., Vallero, D., Eds.; Academic Press: Boston, MA, USA, 2011; Chapter 9, pp. 127-136.

15. Masi, F. Water reuse and resources recovery: The role of constructed wetlands in the Ecosan approach. Desalination 2009, 246, 27-34.

16. Araujo, L.S.; Ramos, H.; Coelho, S.T. Pressure control for leakage minimisation in water distribution systems management. Water Resour. Manag. 2006, 20, 133-149.

17. Mutikanga, H.E.; Vairavamoorthy, K.; Sharma, S.K.; Akita, C.S. Operational tools for decision support in leakage control. Water Pract. Technol. 2011, 6, DOI:10.2166/wpt.2011.057.

18. Charlesworth, S.M.; Harker, E.; Rickard, S. Sustainable Drainage Systems (SuDS): A soft option for hard drainage questions? Geography 2003, 88, 99-107.

19. Domènech, L.; Saurí, D. A comparative appraisal of the use of rainwater harvesting in single and multi-family buildings of the Metropolitan Area of Barcelona (Spain): Social experience, drinking water savings and economic costs. J. Clean. Prod. 2011, 19, 598-608. 
20. Fewkes, A. The use of rainwater for WC flushing: the field testing of a collection system. Build. Environ. 1999, 34, 765-772.

21. Dixon, A.; Butler, D.; Fewkes, A. Water saving potential of domestic water reuse systems using greywater and rainwater in combination. Water Sci. Technol. 1999, 39, 25-32.

22. Liu, B.; Ping, Y. Water saving retrofitting and its comprehensive evaluation of existing residential buildings. Energy Procedia 2012, 14, 1780-1785.

23. Otterpohl, R.; Grottker, M.; Lange, J. Sustainable water and waste management in urban areas. Water Sci. Technol. 1997, 35, 121-133.

24. Charlesworth, S. A review of the adaptation and mitigation of global climate change using sustainable drainage in cities. J. Water Clim. Chang. 2010, 1, 165-180.

25. Massarutto, A. Water pricing and full cost recovery of water services: Economic incentive or instrument of public finance? Water Policy 2007, 9, 591-613.

26. Massarutto, A.; Paccagnan, V.; Linares, E. Private management and public finance in the Italian water industry: A marriage of convenience? Water Resour. Res. 2008, 44, W12425:1-W12425:17.

27. OECD (The Organisation for Economic Co-operation and Development). Pricing Water Resources and Water and Sanitation Services; OECD Publishing: Paris, France, 2010.

28. Save Italy Act; Law No. 214/2011; Gazzetta Ufficiale: Rome, Italy, 2011.

29. Bolognesi, A.; Bragalli, C.; Marchi, A.; Artina, S. Genetic heritage evolution by stochastic transmission in the optimal design of water distribution networks. Adv. Eng. Softw. 2010, 41, 792-801.

30. Cabrera, E.; Pardo, M.A.; Cobacho, R.; Cabrera, E. Energy audit of water networks. J. Water Resour. Plan. Manag. 2010, 136, 669-677.

31. Smits, S.; Bueno Bernal, V.; Celma, J. Zaragoza: Taking Pride in Integrated Water Management in the City; IRC WASH Library: The Hague, The Netherlands, 2010. Available online: http://www.irc.nl/page/62396 (accessed on 27 September 2012).

32. Kaminski, L.E. Technology and Practices outside the Great Lakes-St. Lawrence Region. Great Lakes Commission: Ann Arbor, MI, USA, 2004. Available online: http://www.glc.org/wateruse/ conservation/pdf/BestTechnologiesReport.pdf (accessed on 27 September 2012).

33. Bruxelles Environnement, l'administration de l'environnement et de l'énergie de la Région de Bruxelles-Capitale (In French). Available online: http:/www.bruxellesenvironnement.be/ Templates/Particuliers/informer.aspx?id=3906 (accessed on 27 September 2012).

(C) 2012 by the authors; licensee MDPI, Basel, Switzerland. This article is an open access article distributed under the terms and conditions of the Creative Commons Attribution license (http://creativecommons.org/licenses/by/3.0/). 